\title{
Biomagnification of mercury in an Antarctic marine coastal food web
}

\author{
R. Bargagli*, F. Monaci, J. C. Sanchez-Hernandez, D. Cateni \\ Department of Environmental Biology, University of Siena, Via delle Cerchia 3, I-53100 Siena, Italy
}

\begin{abstract}
Total Hg concentrations were determined in marine sediments and biota from the inner shelf of Terra Nova Bay (Antarctica). Like published data on air, snow and soils from the same region, $\mathrm{Hg}$ levels in the finest fraction of marine sediments were among the lowest ever reported for coastal marine environments $\left(0.012 \pm 0.007 \mathrm{\mu g} \mathrm{g}^{-1}\right.$ dry wt). A progressive increase in $\mathrm{Hg}$ concentrations was found in organisms at different levels of the marine food web (phytoplankton < zooplankton and benthic primary consumers < detritivorous and opportunistic benthic invertebrates < epipelagic fish < demersal fish and plankton-feeding seabirds < fish-eating penguins < predatory birds and Weddell seal). In general, primary producers and consumers showed slightly lower Hg concentrations $10.076 \pm 0.023 \mu \mathrm{g}$ $\mathrm{g}^{-1}$ dry wt) than organisms of related species from other seas, but values in feathers $\left(2.91 \pm 1.93 \mu_{\mathrm{g} \mathrm{g}}{ }^{-1}\right.$ dry wt) of the Antarctic skua and in tissues of a Weddell seal (44.0 and $24.0 \mathrm{\mu g} \mathrm{g}^{-1}$ dry wt in the liver and spleen, respectively) were similar to those in skuas and seals from the northern hemisphere. Trophic connections between organisms in well developed benthic communities, phytoplankton and fish and environmental factors such as enhanced upwelling of cold water, sea ice and low light are deemed to enhance natural biomagnification processes of $\mathrm{Hg}$ in the pristine Antarctic coastal environment.
\end{abstract}

KEY WORDS: Mercury Sediments Coastal food web Biomagnification Ross Sea Antarctica

\section{INTRODUCTION}

Antarctic ecosystems have unique characteristics resulting from a long evolutionary history under extreme environmental conditions. Until recently, they were protected from heavy human impact by their remoteness and inhospitality They therefore constitute a natural laboratory where biogeochemical cycles of metals can be studied under relatively unpolluted environmental conditions.

Despite formidable technical and logistic difficulties, improvements in analytical and ultra-clean sampling techniques in the last decade have led to a better understanding of the environmental distribution and cycling of metals in Antarctica (Boutron \& Patterson 1986, Wolff 1990). With regard to mercury, Antarctic ice-core analyses have provided a reconstruction of

•E-mail: bargagli@unisi.lt atmospheric deposition over the past 34000 yr and emission of gaseous mercury by oceans has been recognised as the principal source of the metal in the Antarctic continent (Vandal et al. 1993). In Victoria Land the lowest mercury concentrations ever reported have been measured in snow (Sheppard et al. 1991), air (de Mora et al. 1993) and soil (Bargagli et al. 1993).

In contrast to the relatively abundant data on environmental abiotic matrices, very little is known of mercury concentrations in Antarctic terrestrial and aquatic biota. Better knowledge of $\mathrm{Hg}$ accumulation in marine organisms at different positions in the food web is important because biomagnification in the aquatic food web is a well known process (D'Itri 1991) and most of the Antarctic biomass is concentrated in the marine environment. Data on mercury levels in Antarctic marine organisms mainly regard species at the top of the food web, such as penguins or marine mammals (McClurg 1984, Honda et al. 1986a, b, Yamamoto et al. 1987a, Szefer et al. 1993). Moreover, 
these data are not unequivocal as differences up to 1 order of magnitude have been reported for similar tissue or organs from the same or closely related animal species. For example, Honda et al. (1986a) found an average mercury concentration of $0.007 \mu \mathrm{g} \mathrm{g}^{-1}$ (wet wt) in muscle of the Adélie penguin Pygoscelis adeliae, whereas Szefer et al. (1993) reported a mean value of $0.660 \mathrm{\mu g} \mathrm{g}^{-1}$ (dry wt). Even the most recent data on mercury concentrations in some marine invertebrates and fish contain discrepancies. Much lower $\mathrm{Hg}$ concentrations have been reported for organisms collected along the Antarctic Peninsula (Palmer Locarnini \& Presley 1995, de Moreno et al. 1997) than in Victoria Land (Minganti et al. 1994). This is rather surprising because the latter is more remote and less frequented by humans.

The main objectives of this study were to investigate $\mathrm{Hg}$ transfer and biomagnification in the marine food web and the ecological factors involved in these processes. Mercury concentrations were determined in recent marine sediment and a large spectrum of organisms with different habitats, positions in the food web and feeding habits from the inner continental shelf at Terra Nova Bay (Ross Sea, Antarctica).
Sampling of higher vertebrate species was planned so as to avoid death or significant disturbance. On the coast around Terra Nova Bay, eggs, primary feathers, chick plumage and guano samples were gathered when possible in abandoned nests of snow petrels Pagadroma nivea, Antarctic skuas Catharacta maccormicki, Adélie penguins Pygoscelis adeliae and emperor penguins Aptenodytes forsteri. Samples of stomach contents were taken from 5 Adélie penguins breeding at Edmonson Point ( $74^{\circ} 21^{\prime} \mathrm{S}, 165^{\circ} 10^{\prime} \mathrm{E}$ ) by the water off-loading. Various internal organs and tissues were obtained from an Adélie penguin accidentally snared in a trammel net and an adult female Weddell seal Leptonychotes weddellii (weight $=330 \mathrm{~kg}$ ) found dead on the Terra Nova Bay coast.

To reduce contamination, samples were always handled with disposable plastic gloves, very clean plastic or stainless steel tools, and placed in individual sealed polythene bags and frozen for storage and transport to Italy.

Sample preparation and mercury analysis. In the laboratory, sediment samples were freeze-dried and then sieved through a $125 \mu \mathrm{m}$ stainiess steei screen. Composite samples of phytoplankton (mainly diatoms

\section{MATERIALS AND METHODS}

Study area and sampling. Samples were collected during the 5th and 6th Italian Antarctic Expeditions (austral summers 1989/90 and 1990/91) at Terra Nova Bay (northern Victoria Land; Fig. 1). Surface sediments and organisms were collected on the inner continental shelf (from $74^{\circ} 40^{\prime} \mathrm{S}$ to $74^{\circ} 50^{\prime} \mathrm{S}$ ) at depths ranging from 5 to $300 \mathrm{~m}$, except for krill Euphausia superba samples which were collected in the open Ross Sea (from $72^{\circ}$ to $75^{\circ} \mathrm{S}$ and $170^{\circ}$ and $178^{\circ} \mathrm{E}$ ).

Twenty samples of surface sediments (the top $3.0 \mathrm{~cm}$ ) were taken on soft bottoms (from 20 to $300 \mathrm{~m}$ depth) with a stainless steel box corer. Samples were scooped from the centre of the box with a plastic spatula. Phytoplankton and zooplankton were sampled with conical nylon nets $(1 \mathrm{~m}$ in diameter, 50 and $500 \mu \mathrm{m}$ mesh size, respectively), towed just below the surface. Krill samples were collected in the Ross Sea with a plankton sampler (EZNET BIONESS) equipped with 10 nets of 250 and $500 \mu \mathrm{m}$ mesh size at a depth ranging from 10 to $100 \mathrm{~m}$. Benthic organisms were obtained with a Van Veen grab or by dredging on hard bottoms. Fish specimens were caught with a trammel net or baited long lines.

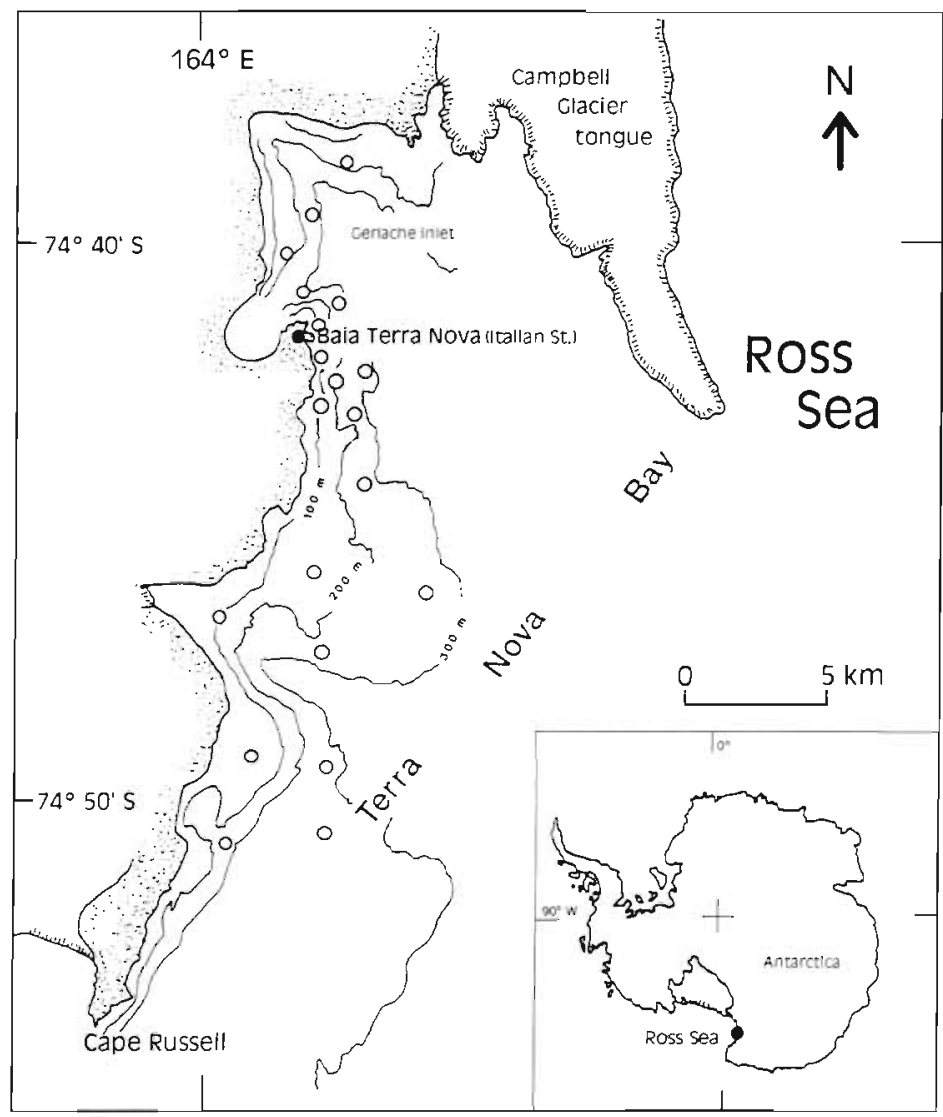

Fig. 1. Map showing the study area and sediment sampling points (0) 
of the genera Nitzschia and Chaetoceros), seaweeds Iridaea cordata, zooplankton (mainly the copepods Metridia gerlachei and Euchaeta antarctica), sponges (belonging to the genera Rossella, Tedania and Axociella), ascidians, the common amphipod Paramoera walkeri and the polychaete Harmothoe spinosa were freeze-dried. All the other organisms, the bivalve molluscs Laternula elliptica and Adamussium colbecki, the gastropod Neobuccinum eatoni, the sea urchin Sterechinus neumayeri, the sea star Odonaster validus and fish belonging to the genus Trematomus ( $T$. bernacchii, $T$. hansoni, $T$. newnesi) and icefish Chionodraco hamatus, were thawed, identified as to genus or species, and body length and other basic morphometric parameters recorded. Whenever possible muscle, liver (or the digestive gland), gills, kidney, soft tissue and gonads were removed and lyophilised. Prior to the analytical determinations, feathers were carefully cleaned of loosely attached material and each egg albumen separated and freeze-dried. Sediment samples were vacuum-dried and then passed through a $125 \mu \mathrm{m}$ stainless steel sieve to reduce the effects of grain-size variations on Hg concentrations.

A subsample $(0.15 \mathrm{~g})$ of homogenised superficial sediment and biological material was decomposed with concentrated $\mathrm{HNO}_{3}$ (Merck Suprapur) in Teflon vessels under pressure at $120^{\circ} \mathrm{C}$ for $8 \mathrm{~h}$. Mercury was determined in the digested solution by Flow Injection Atomic Absorption Spectrometry (FIAAS) using a Perkin Elmer FIMS 400. Hg determinations were based on 3 replicates. The precision of $\mathrm{Hg}$ determinations, expressed as the coefficient of variation on repeated assays of the same sample, was about $5 \%$. The minimum detection limit in $\mu g g^{-1}$ dry wt was 0.005. Each series of analysis was accompanied by concurrent mineralisation and determination of Standard Reference Materials (SRMs) no. 1646 'Estuarine Sediment' and no. 1577 'Bovine Liver' from NIST (Gaithersburg, USA). Batches with accompanying SRMs outside the certified range were repeated. The recovery rate ranged from 86 to $109 \%$, the average being $92 \%$ for sediments and $96 \%$ for biotic samples. Subsamples of superficial sediment were analysed for total organic carbon (TOC) content by a modified Walkley-Black titration method (Gaudette et al. 1974).

Nonparametric statistical tests (Mann-Whitney $U$ test) were used to detect significant differences between groups. Pearson's correlation coefficients were also calculated for the relationship between mercury concentration and body weight. A probability level of 0.05 was taken as significant. All statistical analyses were performed using the Statistica programme (StatSoft Inc.).

\section{RESULTS}

The fine fraction $(<125 \mu \mathrm{m})$ of surface sediments from Terra Nova Bay had an average $\mathrm{Hg}$ concentration $\left( \pm \mathrm{SD}\right.$ ) of $0.012 \pm 0.007 \mathrm{\mu g} \mathrm{g}^{-1}$ dry wt (range 0.006 to $0.027 \mathrm{ug} \mathrm{g}^{-1}$ dry wt). Values were always much lower than the $\mathrm{Hg}$ concentration (0.050 $\mathrm{\mu g} \mathrm{g}^{-1}$ dry wt) suggested as background level for unpolluted marine sediments (Sadiq 1992). No significant increase was found in samples collected close to the Italian scientific station of 'Baia Terra Nova'. Concentrations of TOC ranged from 0.20 to $0.55 \%$ and no significant relationships with those of $\mathrm{Hg}$ were found.

Average $\mathrm{Hg}$ concentrations (Table 1) progressively increased in the order phytoplankton < zooplankton < krill. Because $\mathrm{Hg}$ values in zooplankton had a CV of $47.5 \%$ (probably due to different proportions of the various phyla in samples), a statistically significant difference (Mann-Whitney $U$ test, $p<0.05$ ) was only found between $\mathrm{Hg}$ concentrations in phytoplankton and krill. Comparisons with literature data on plankton from other seas were made difficult by differences in sampling methods and phyla composition. Fowler (1990) assumed a $\mathrm{Hg}$ concentration of $0.100 \mu \mathrm{g} \mathrm{g}^{-1}$ dry wt (i.e. twice the overall average content of $0.059 \pm$ $0.033 \mu \mathrm{g} \mathrm{g}^{-1}$ dry wt in Antarctic diatoms and copepods) as background level for mixed plankton samples from different seas around the world. The average $\mathrm{Hg}$ concentration in krill samples from the Ross Sea was close to the lower limit of the range $\left(0.028\right.$ to $0.497 \mu^{-1} g^{-1}$ dry wt) reported by Fowler (1986) for euphausiids from different oceans. However, the data in Table 1 are 2 to 3 times higher than those reported for krill samples collected on the opposite side of the Southern Ocean: $0.035 \mu \mathrm{g} \mathrm{g}^{-1}$ dry wt in the Drake Passage (Yamamoto et al. $1987 \mathrm{~b})$ and $0.025 \mu \mathrm{g} \mathrm{g}^{-1}$ dry wt off the Western Antarctic Peninsula (Palmer Locarnini \& Presley 1995).

The results of $\mathrm{Hg}$ determinations in the widespread seaweed Iridaea cordata showed wide variations (approximately 1 order of magnitude), probably due to different contributions of epibiota on the foliaceous thalli (Table 1). The range of $\mathrm{Hg}$ concentrations in $I$. cordata was similar to that previously found in other Rhodophyta species from the Great Barrier Reef (undetectable to $0.167 \mathrm{\mu g} \mathrm{g}^{-1} \mathrm{dry}_{\mathrm{wt}}$ Denton \& Burdon-Jones 1986). High variability in $\mathrm{Hg}$ concentrations was also found among the benthic invertebrates analysed, probably reflecting marked differences in taxonomy, habitat and feeding habits. The total body content of mercury increased from organisms feeding mainly on diatoms, such as the amphipod Paramoera walkeri and sponges, to those feeding on algae and/or detritus (e.g. ascidians, sea urchins and holothurians) and to more omnivorous opportunistic feeders (e.g. scavengers and predators such as brittle stars and sea stars). The high- 
Table 1. Mercury concentrations ( $\mu \mathrm{g} \mathrm{g}^{-1}$ dry wt) in invertebrates from Terra Nova Bay (Ross Sea, Antarctica)

\begin{tabular}{|c|c|c|c|c|c|}
\hline Taxon & Species & Tissue & $n$ & Mean \pm SD & Min-max. \\
\hline Phytoplankton & Pooled across species & & 6 & $0.039 \pm 0.007$ & $0.028-0.047$ \\
\hline Zooplankton & Pooled across species & & 6 & $0.065 \pm 0.038$ & $0.048-0.150$ \\
\hline Krill $^{\mathrm{d}}$ & Pooled across species & & 6 & $0.077 \pm 0.026$ & $0.050-0.105$ \\
\hline Rhodophyta & Iridaea cordata & Whole & 8 & $0.12 \pm 0.07$ & $0.02-0.17$ \\
\hline Porifera & Pooled across species & Whole & 9 & $0.08 \pm 0.05$ & $0.03-0.18$ \\
\hline Ascidiacea & Pooled across species & Whole & 4 & $0.10 \pm 0.08$ & $0.03-0.20$ \\
\hline \multicolumn{6}{|l|}{ Echinodermata } \\
\hline Holothuroidea & Pooled across species & Whole & 19 & $0.23 \pm 0.09$ & $0.08-0.38$ \\
\hline Ophiuroidea & Pooled across species & Whole & 8 & $0.1 .1 \pm 0.04$ & $0.06-0.16$ \\
\hline Asteroidea & Odontaster validus & $\begin{array}{l}\text { Arms } \\
\text { Soft tissue } \\
\text { Gonads }\end{array}$ & $\begin{array}{r}16 \\
16 \\
6\end{array}$ & $\begin{array}{l}0.11 \pm 0.06 \\
0.17 \pm 0.10 \\
0.09 \pm 0.07\end{array}$ & $\begin{array}{l}0.06-0.22 \\
0.07-0.36 \\
0.06-0.20\end{array}$ \\
\hline Echinoidea & Sterechinus neumayeri & $\begin{array}{l}\text { Soft tissue } \\
\text { Gonads }\end{array}$ & $\begin{array}{l}11 \\
10\end{array}$ & $\begin{array}{l}0.09 \pm 0.05 \\
0.13 \pm 0.07\end{array}$ & $\begin{array}{ccc}0.02 & 0.18 \\
0.02 & 0.21\end{array}$ \\
\hline Annelida & Harmothoe spinosa & Whole & 6 & $0.07 \pm 0.02$ & $0.03-0.11$ \\
\hline \multicolumn{6}{|l|}{ Crustacea } \\
\hline Pycnogonida & Colossendeis australis & Whole & 9 & $0.16 \pm 0.05$ & $0.09-0.20$ \\
\hline \multicolumn{6}{|l|}{ Mollusca } \\
\hline \multirow[t]{2}{*}{ Bivalvia } & Adamussium colbecki & $\begin{array}{l}\text { Muscle } \\
\text { Digestive gland } \\
\text { Gonads } \\
\text { Gills }\end{array}$ & $\begin{array}{l}12 \\
12 \\
12 \\
12\end{array}$ & $\begin{array}{l}0.20 \pm 0.10 \\
0.35 \pm 0.08 \\
0.27 \pm 0.14 \\
0.86 \pm 0.22\end{array}$ & $\begin{array}{l}0.11-0.41 \\
0.23-0.49 \\
0.05-0.53 \\
0.36-1.17\end{array}$ \\
\hline & Laternula elliptica & $\begin{array}{l}\text { Muscle } \\
\text { Digestive gland } \\
\text { Gonads } \\
\text { Gills }\end{array}$ & $\begin{array}{r}9 \\
10 \\
6 \\
5\end{array}$ & $\begin{array}{l}0.24 \pm 0.08 \\
0.21 \pm 0.06 \\
0.24 \pm 0.11 \\
0.39 \pm 0.20\end{array}$ & $\begin{array}{l}0.11-0.34 \\
0.12-0.30 \\
0.11-0.40 \\
0.27-0.68\end{array}$ \\
\hline Prosobranchia & Neobuccinum eatoni & $\begin{array}{l}\text { Muscle } \\
\text { Digestive gland } \\
\text { Gonads }\end{array}$ & $\begin{array}{r}10 \\
10 \\
7\end{array}$ & $\begin{array}{l}0.28 \pm 0.15 \\
0.24 \pm 0.10 \\
0.18 \pm 0.09\end{array}$ & $\begin{array}{l}0.10-0.60 \\
0.10-0.38 \\
0.05-0.27\end{array}$ \\
\hline
\end{tabular}

est $\mathrm{Hg}$ levels were recorded in gills of filter-feeding benthic molluscs, especially those of the Antarctic scallop Adamussium colbecki.

Data on $\mathrm{Hg}$ concentrations in benthic organisms from the Southern Ocean are scarce. In a survey by de Moreno et al. (1997), a large number of species collected from different sites off the Antarctic Peninsula were analysed for $\mathrm{Hg}$. The authors were unable to detect $\mathrm{Hg}$ even in carnivore invertebrates such as the gastropod Trophon brevispira and the giant isopod Glyptonotus antarcticus. Unfortunately only wet tissues were analysed and the detection limit $\left(0.05 \mu \mathrm{g} \mathrm{g}^{-1}\right.$ wet wt) was probably too high for detecting the low levels, typical of Antarctic ecosystems. There is also evidence that Antarctic benthic invertebrates, especially molluscs, accumulate metals (Mauri et al. 1990, Nigro et al. 1997) and Adamussium colbecki has been proposed as a suitable biomonitor to detect environmental changes in metal bioavailability in Antarctic coastal waters (Berkman \& Nigro 1992). Minganti et al. (1995) reported $\mathrm{Hg}$ concentrations ranging from 0.132 to $0.372 \mu \mathrm{g} \mathrm{g}^{-1}$ dry wt in the soft tissue of $A$. colbecki collected each summer from 1987 to 1992 at Terra Nova Bay.

Total Hg concentrations in muscle, liver, kidney, gills and gonads of the most common fish species in the study area are summarised in Table 2. Trematomus bernacchii and Trematomus hansonishowed significantly $(p<0.01$, Mann-Whitney $U$ test) higher concentrations of $\mathrm{Hg}$ in muscle and organs than Trematomus newnesi and the icefish Chionodraco hamatus. Fig. 2A shows average values of $\mathrm{Hg}$ measured in muscle, liver and kidney of $T$ bernacchii and those previously reported for this species from Terra Nova Bay continental shelf (Minganti et al. 
Table 2. Mercury concentrations ( $\mathrm{kg} \mathrm{g}^{1} \mathrm{dry}$ wt) in fish of the genus Trematomus and in the icefish Chionodraco hamatus from Terra Nova Bay continental shelf

\begin{tabular}{|c|c|c|c|c|c|c|}
\hline Species & Length $(\mathrm{cm})$ & Weight $(g)$ & Tissue & $\mathrm{n}$ & Mean $\pm S D$ & Min.-max \\
\hline$T$ bernacchij & $17-28$ & $83-354$ & $\begin{array}{l}\text { Muscle } \\
\text { Liver } \\
\text { Kidney } \\
\text { Gills } \\
\text { Gonads }\end{array}$ & $\begin{array}{l}12 \\
11 \\
10 \\
13 \\
10\end{array}$ & $\begin{array}{l}0.83 \pm 0.65 \\
0.46 \pm 0.25 \\
0.94 \pm 0.64 \\
0.34 \pm 0.17 \\
0.26 \pm 0.14\end{array}$ & $\begin{array}{l}0.17-1.79 \\
0.10-0.82 \\
0.32-2.60 \\
0.18-0.74 \\
0.11-0.45\end{array}$ \\
\hline$T$ hansoni & $23-32$ & $147-340$ & $\begin{array}{l}\text { Muscle } \\
\text { Liver } \\
\text { Kidney } \\
\text { Gills } \\
\text { Gonads }\end{array}$ & $\begin{array}{r}15 \\
18 \\
13 \\
13 \\
9\end{array}$ & $\begin{array}{l}0.47 \pm 0.32 \\
0.23 \pm 0.16 \\
1.06 \pm 0.46 \\
0.44 \pm 0.28 \\
0.20 \pm 0.12\end{array}$ & $\begin{array}{l}0.11-1.08 \\
0.08-0.69 \\
0.10-1.75 \\
0.10-1.01 \\
0.02-0.38\end{array}$ \\
\hline T. newnesi & $20-25$ & $89-194$ & $\begin{array}{l}\text { Muscle } \\
\text { Liver } \\
\text { Kidney } \\
\text { Gills } \\
\text { Gonads }\end{array}$ & $\begin{array}{l}7 \\
7 \\
8 \\
3 \\
3\end{array}$ & $\begin{array}{l}0.29 \pm 0.24 \\
0.16 \pm 0.09 \\
0.27 \pm 0.15 \\
0.06 \pm 0.02 \\
0.19 \pm 0.08\end{array}$ & $\begin{array}{l}0.09-0.82 \\
0.09-0.28 \\
0.09-0.82 \\
0.05-0.08 \\
0.11-0.28\end{array}$ \\
\hline C. hamatus & $33-39$ & $270-615$ & $\begin{array}{l}\text { Muscle } \\
\text { Liver } \\
\text { Kidney } \\
\text { Gills } \\
\text { Gonads }\end{array}$ & $\begin{array}{r}7 \\
18 \\
20 \\
13 \\
17\end{array}$ & $\begin{array}{l}0.34 \pm 0.33 \\
0.19 \pm 0.12 \\
0.28 \pm 0.20 \\
0.14 \pm 0.09 \\
0.21 \pm 0.09\end{array}$ & $\begin{array}{l}0.01-0.92 \\
0.02-0.44 \\
0.10-0.85 \\
0.01-0.29 \\
0.01-0.35\end{array}$ \\
\hline
\end{tabular}

1994). According to Capelli et al. (1990), concentrations of $\mathrm{Hg}$ in fish muscle wcre significantly correlated $(\mathrm{r}=$ $0.81, \mathrm{p}<0.01$ ) with body weight (Fig. 2B).

The accumulation of $\mathrm{Hg}$ in seabirds breeding along Victoria Land coasts was evaluated by an indirect nondestructive approach (Table 3). Concentrations of $\mathrm{Hg}$ in feathers, eggs and chick plumage of the south polar skua were 3 to 6 times higher than those measured in the same biological materials of snow petrels and penguins. Samples collected in the emperor penguin colony at Cape Washington always had higher concentrations of total $\mathrm{Hg}$ than samples from Adélie penguin rookeries on the Terra Nova Bay coast.

Although comparisons with literature data on $\mathrm{Hg}$ levels in feathers of related seabird species from other seas are made difficult by factors such as differences in lifespan and moulting strategies (Stewart et al. 1997), $\mathrm{Hg}$ concentrations in snow petrels breeding in northern Victoria Land were much lower than those reported for other petrel species (e.g. Pterodroma lessonii and Macronectes halli) from subantarctic islands (Lock et al. 1992). Emperor and Adélie penguin feathers also had a much lower content of $\mathrm{Hg}$ than those of blue penguins Eudyptula minor from New Zealand (Table 3). In contrast, feathers and chick plumage of the Antarctic skua Catharactra maccormicki and Arctic skua Stercorarius parasiticus from the Shetland Islands $\left(60^{\circ} 08^{\prime} \mathrm{N}, 2^{\circ} 05^{\prime} \mathrm{W}\right)$ had $\mathrm{Hg}$ concentrations in the same range (Stewart et al. 1997).

Average $\mathrm{Hg}$ in stomach contents of Adélie penguins matched those in krill samples, whereas penguin tissues
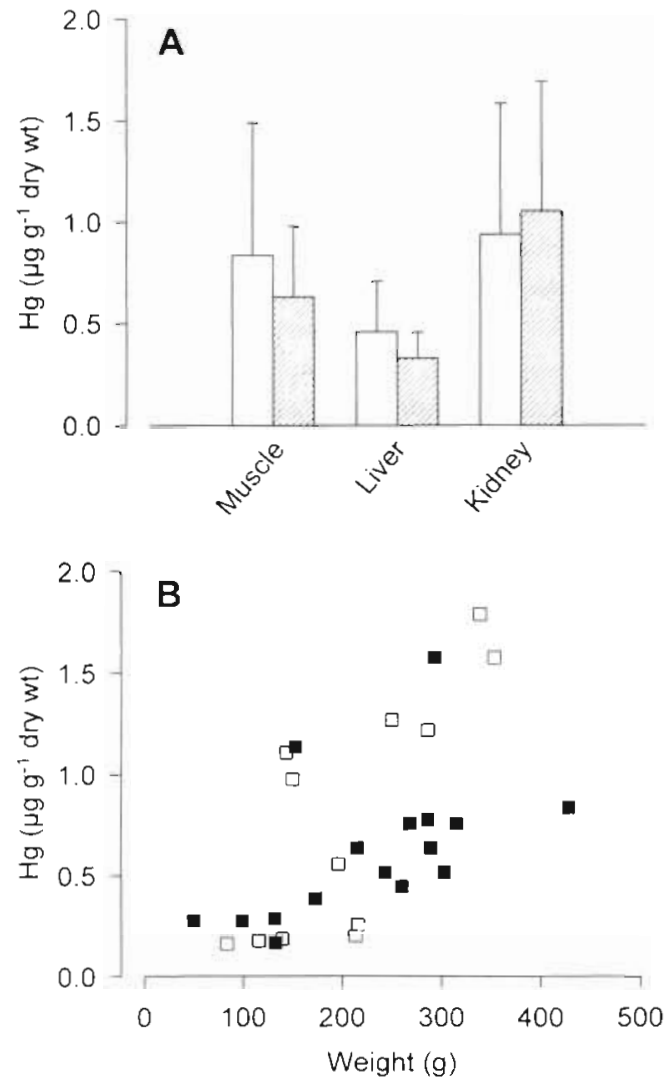

Fig. 2. (A) Comparison between total $\mathrm{Hg}$ concentration in muscle, liver and kidney of Trematomus bernacchii from the current study (white bar) and data from Minganti et al. (1994) (shaded bar). (B) Relationship between total Hg concentrations in muscle and body weight in this study ( $\square$ ) and data from Capelli et al. (1990) 
showed increasing concentrations in the order testis < brain < muscle < kidney < liver (Table 4). According to published data on Pygoscelis adeliae (Szefer et al. 1993), Eudyptula minor, Eudyptes crestatus and Eudyptes sclateri (Lock et al. 1992), Hg concentrations (dry wt) in penguin liver range from 1.4 to $2.4 \mathrm{\mu g} \mathrm{g}^{-1}$ irrespective of species and sampling area. The only exception was a lower concentration measured by Lock et al. (1992) in the liver of a Fiordland crested penguin Eudyptes pachyrhynchus. Although on a wet weight basis, the concentrations reported by Honda et al. (1986a) in Adélie penguins and by de Moreno et al. (1997) in muscle of the same species are lower than all other data (Table 4).

The highest mercury concentrations of the present study were recorded in liver of the Weddell seal (44.0 $\mathrm{kg} \mathrm{g}^{-1}$ dry wt) found dead on the Terra Nova Bay coast. Much lower concentrations were detected in splcon, muscle and pancreas (Table 5). Although expressed on a wet weight basis, the values reported by Yamamoto et al. (1987a) in 2 Weddell seals from the Syowa Station were lower than those in our specimen. However, except for low concentrations reported for muscle of Arctocephalus gazella (de Moreno et al. 1997 ) and liver of Ommatophoca rossi (McClurg 1984) and Phoca groenlandica (Skaare et al. 1994), the present values were in the same range as those reported for adult seals of other species in the southern and northern hemispheres (Table 5).

\section{DISCUSSION}

\section{Environmental distribution and bioavailability of $\mathrm{Hg}$}

Very low concentrations of total $\mathrm{Hg}$ were measured in the finest fraction of recent marine sediments from Terra Nova Bay. This result, together with previous findings for snow, air and soil (Sheppard et al. 1991,

Table 3. Mercury concentrations ( $\mu \mathrm{g} \mathrm{g}^{-1}$ dry wt) in eggs, adult body feathers, guano and chick plumage from Terra Nova Bay seabirds. Literature data on related species is also reported for comparison

\begin{tabular}{|c|c|c|c|c|c|}
\hline Species & Region & Sample & $\mathrm{n}$ & Mean $\pm \mathrm{SD}$ & Source \\
\hline \multicolumn{6}{|l|}{ Petrels } \\
\hline Pagodroma nivea & Terra Nova Bay & $\begin{array}{l}\text { Eggs }^{\alpha} \\
\text { Feathers }\end{array}$ & $\begin{array}{l}3 \\
5\end{array}$ & $\begin{array}{l}0.59 \pm 0.08 \\
0.54 \pm 0.18\end{array}$ & $\begin{array}{l}\text { This study } \\
\text { This study }\end{array}$ \\
\hline Pterodroma cooki & Subantarctic Islands & Feathers & 1 & 12.4 & Lock et al. (1992) \\
\hline Pterodroma lessonii & Subantarctic Islands & Feathers & 1 & 24.4 & Lock et al. (1992) \\
\hline Daption capense & Subantarctic Islands & Feathers & 1 & 1.3 & Lock et al. (1992) \\
\hline Macronectes halli & Subantarctic Islands & Feathers & 1 & 24.0 & Lock et al. (1992) \\
\hline Macronectes giganteus & New Zealand & Feathers & 44 & $11.0 \pm 6.1$ & Thompson et al. (1993) \\
\hline $\begin{array}{l}\text { Skuas } \\
\text { Catharacta maccormicki }\end{array}$ & Terra Nova Bay & $\begin{array}{l}\text { Eggs }^{\mathrm{a}} \\
\text { Feathers } \\
\text { Guano } \\
\text { Chick plumage }\end{array}$ & $\begin{array}{l}4 \\
7 \\
6 \\
1\end{array}$ & $\begin{array}{c}1.61 \pm 1.22 \\
2.91 \pm 1.93 \\
0.22 \pm 0.10 \\
1.90\end{array}$ & $\begin{array}{l}\text { This study } \\
\text { This study } \\
\text { This study } \\
\text { This study }\end{array}$ \\
\hline Catharacta skua & Shetland & $\begin{array}{l}\text { Adult feathers } \\
\text { Chick down } \\
\text { Chick feathers }\end{array}$ & $\begin{array}{l}54 \\
58 \\
28\end{array}$ & $\begin{array}{l}6.34 \pm 2.60 \\
4.15 \pm 1.39 \\
1.22 \pm 0.38\end{array}$ & $\begin{array}{l}\text { Stewart et al. (1997) } \\
\text { Stewart et al. (1997) } \\
\text { Stewart et al. (1997) }\end{array}$ \\
\hline Stercorarius parasiticus & Shetland & $\begin{array}{l}\text { Adult feathers } \\
\text { Chick down } \\
\text { Chick feathers }\end{array}$ & $\begin{array}{l}28 \\
36 \\
30\end{array}$ & $\begin{array}{l}2.52 \pm 2.23 \\
2.00 \pm 0.91 \\
0.46 \pm 0.22\end{array}$ & $\begin{array}{l}\text { Stewart et al. (1997) } \\
\text { Stewart et al. (1997) } \\
\text { Stewart et al. (1997) }\end{array}$ \\
\hline $\begin{array}{l}\text { Penguins } \\
\text { Pygoscelis adeliae }\end{array}$ & Terra Nova Bay & $\begin{array}{l}\text { Egg } \\
\text { Feathers } \\
\text { Guano } \\
\text { Chick plumage } \\
\text { Stomach content }\end{array}$ & $\begin{array}{r}13 \\
3 \\
7 \\
11 \\
5\end{array}$ & $\begin{array}{l}0.26 \pm 0.08 \\
0.82 \pm 0.13 \\
0.17 \pm 0.10 \\
0.37 \pm 0.15 \\
0.08 \pm 0.01\end{array}$ & $\begin{array}{l}\text { This study } \\
\text { This study } \\
\text { This study } \\
\text { This study } \\
\text { This study }\end{array}$ \\
\hline Pygoscelis adeliae & Syowa station & Feathers & 10 & $0.17 \pm 0.04$ & Honda et al. (1986b) \\
\hline Aptenodytes forsteri & Terra Nova Bay & $\begin{array}{l}\text { Feathers } \\
\text { Guano } \\
\text { Chick plumage }\end{array}$ & $\begin{array}{l}3 \\
5 \\
1\end{array}$ & $\begin{array}{c}0.98 \pm 0.21 \\
0.31 \pm 0.03 \\
0.67\end{array}$ & $\begin{array}{l}\text { This study } \\
\text { This study } \\
\text { This study }\end{array}$ \\
\hline Eudyptula minor & Subantarctic Islands & Feathers & 5 & $3.40 \pm 3.70$ & Lock et al. (1992) \\
\hline
\end{tabular}


Table 4. Mercury concentrations ( $\mu \mathrm{g} \mathrm{g}^{-1} \mathrm{dry} w \mathrm{t}$ ) in tissues of an Adélie penguin compared with literature data on penguins from other Antarctic and subantarctic regions

\begin{tabular}{|c|c|c|c|c|}
\hline Region & Species & $\mathrm{n}$ & Mean $\pm \mathrm{SD}$ & Source \\
\hline \multicolumn{5}{|l|}{ Muscle } \\
\hline Terra Nova Bay & Pygoscelis adeliae & 1 & 0.60 & This study \\
\hline Antarctic Peninsula & P. adeliae & 5 & 0.63 & Szefer et al. (1993) \\
\hline Antarctic Peninsula & P. adeliae & - & $0.003^{\mathrm{a}}$ & de Moreno et al. (1997) \\
\hline Syowa station & P. adeliae & 10 & $0.007 \pm 0.002^{\mathrm{d}}$ & Honda et al. (1986b) \\
\hline Antarctic Peninsula & P. papua & - & $0.003^{\mathrm{a}}$ & de Moreno et al. (1997) \\
\hline \multicolumn{5}{|l|}{ Liver } \\
\hline Terra Nova Bay & P. adeliae & 1 & 1.60 & This study \\
\hline \multirow[t]{2}{*}{ Antarctic Peninsula } & P. adeliae & - & $0.60^{a}$ & de Moreno et al. (1997) \\
\hline & P. adeliae & 6 & 2.01 & Szefer et al. (1993) \\
\hline \multirow[t]{2}{*}{ Bouvetøya Island } & P. antarctica & 13 & $0.50^{\mathrm{d}}$ & Norheim (1987) \\
\hline & Eudyptes chrysolophus & 9 & $0.90^{a}$ & Norheim (1987) \\
\hline \multirow[t]{4}{*}{ Subantarctic Islands } & Eudyptula minor & 6 & $1.40 \pm 1.40$ & Lock et al. (1992) \\
\hline & Eudyptes crestatus & 2 & $1.50 \pm 0.70$ & Lock et al. (1992) \\
\hline & E. pachyrhynchus & 1 & 0.50 & Lock et al. (1992) \\
\hline & E. sclateri & 4 & $2.40 \pm 1.20$ & Lock et al. (1992) \\
\hline \multicolumn{5}{|l|}{ Kidney } \\
\hline Terra Nova Bay & P. adeliae & 1 & 1.20 & This study \\
\hline Syowa station & P. adeliae & 10 & $0.06 \pm 0.06^{\mathrm{a}}$ & Honda et al. $(1986 b)$ \\
\hline \multicolumn{5}{|l|}{ Brain } \\
\hline Terra Nova Bay & P. adeliae & 1 & 0.43 & This study \\
\hline Syowa station & P. adeliae & 1 & $0.003^{a}$ & Honda et al. (1986b) \\
\hline \multicolumn{5}{|l|}{ Testis } \\
\hline Terra Nova Bay & P. adeliae & 1 & 0.42 & This study \\
\hline
\end{tabular}

Bargagli et al. 1993, de Mora et al. 1993) confirms that abiotic matrices in Victoria Land ecosystems have the lowest $\mathrm{Hg}$ concentrations ever reported. In the study area, this result was expected as Southern Ocean waters are substantially isolated from those of other oceans and long-range atmospheric loadings of $\mathrm{Hg}$ can be excluded on the basis of $\mathrm{Hg}$ deposition data (Vandal et al. 1993). Although the physical and chemical weathering of rocks in Antarctica is limited by the ice cover and dry climate, the results of analytical determinations in surface sediments from Terra Nova Bay seem to exclude local $\mathrm{Hg}$ deposits and pollution by the Italian station.

Regional volcanic emissions are a possible natural source of $\mathrm{Hg}$ in the Ross Sea. The significance of valcanic emissions as primary sources of $\mathrm{Hg}$ is well documented (Varekamp \& Buseck 1986) and the McMurdo Volcanic Group along the western margin of the Ross Embayment is one of the most extensive alkali volcanic provinces in the world (Kyle 1990). Besides active volcanoes (Mt. Erebus and Mt. Melbourne), there are fumaroles in northern Victoria Land (Bargagli et al. 1996a) and recent submarine volcanoes and/or large intrusive bodies in the western Ross Sea (Kyle 1990).
Air and snow data, however, suggest that the impact of these emissions is very low. Thus, an explanation for the accumulation of $\mathrm{Hg}$ in Terra Nova Bay organisms should be sought among the peculiar physico-chemical characteristics of this marine environment and adaptation mechanisms of Antarctic organisms, achieved through a long evolutionary history.

The Ross Sea is a wide embayment of the continental shelf between Cape Adare and Cape Colbeck with an average depth of $550 \mathrm{~m}$. Water temperature is always low, ranging from $1^{\circ} \mathrm{C}$ in summer to $-2.0^{\circ} \mathrm{C}$ in winter at the surface. Summer availability of the light makes primary production and wintering strategies of primary producers and consumers highly seasonal. Moreover, in the southernmost part of Terra Nova Bay, a strong katabatic wind determines the recurrence of a coastal polynya (Kurtz \& Bromwich 1985) which enhances the upwelling of deep nutrient-rich waters that favour primary production (up to $1119 \mathrm{mgC} \mathrm{m}^{-2}$ $\mathrm{d}^{-1}$ in the 0 to $50 \mathrm{~m}$ layer; Innamorati et al. 1992). The phytoplankton blooms twice in summer: once during the melt and again during the ice formation; variations in underwater irradiance are mainly due to the phytoplankton biomass (Innamorati et al. 1992). 
Table 5. Mercury concentrations ( $\mu \mathrm{g} \mathrm{g}^{-1} \mathrm{dry}$ wt) in tissues of an adult Weddell seal from Terra Nova Bay compared with Hg levels in seals from other regions

\begin{tabular}{|c|c|c|c|c|}
\hline Region & Species & $\mathrm{n}$ & Mean $\pm \mathrm{SD}$ & Source \\
\hline \multicolumn{5}{|l|}{ Muscle } \\
\hline Terra Nova Bay & Leptonychotes weddellii & 1 & $1.85^{\mathrm{a}}$ & This study \\
\hline \multirow[t]{2}{*}{ Syowa station } & L. weddellii & 2 & $0.16^{\mathrm{ca}}$ & Yamamoto et al. (1987a) \\
\hline & & & $0.11^{c b}$ & Yamamoto et al. (1987a) \\
\hline \multirow[t]{4}{*}{ Antarctic Peninsula } & L. weddellii & 1 & $3.61^{\mathrm{d}}$ & Szefer et al. (1993) \\
\hline & & 1 & $1.18^{\mathrm{L}}$ & Szefer et al. (1993) \\
\hline & Lobodon carcinophagus & 11 & 6.22 & Szefer et al. (1993) \\
\hline & Hydrurga leptonyx & 2 & 3.22 & Szefer et al. (1993) \\
\hline Gulf of St. Lawrence & Phoca groenlandica & 20 & $1.32 \pm 0.81$ & Wagemann et al. (1988) \\
\hline Eastern Australia & Arctocephalus pusillus & 16 & $0.91 \pm 0.52^{r}$ & Bacher (1985) \\
\hline Antarctic Peninsula & A. gazella & 4 & $<0.05^{c}$ & de Moreno et al. (1997) \\
\hline \multicolumn{5}{|l|}{ Liver } \\
\hline Terra Nova Bay & L. weddellii & 1 & $44.0^{\mathrm{a}}$ & This study \\
\hline \multirow[t]{2}{*}{ Syowa station } & L. weddellii & 2 & $3.10^{c \cdot d}$ & Yamamoto et al. (1987a) \\
\hline & & & $8.50^{c, b}$ & Yamamolu ei al. (1987a) \\
\hline \multirow[t]{4}{*}{ Antarctic Peninsula } & L. weddellii & 1 & $48.8^{\mathrm{d}}$ & Szefer et al. (1993) \\
\hline & & 1 & $21.1^{b}$ & Szefer et al. (1993) \\
\hline & Lobodon carcinophagus & 11 & 5.15 & Szefer et al. (1.993) \\
\hline & Hydrurga leptonyx & 2 & 18.1 & Szefer et al. (1993) \\
\hline Eastern Australia & A. pusillus & 16 & $62.3 \pm 44.7^{c}$ & Bacher (1985) \\
\hline Antarctic Peninsula & A. gazella & 4 & $5.50 \pm 1.50^{r}$ & de Moreno et al. (1997) \\
\hline Alejandro Selkirk Is. & A. philippii & 1 & 75.09 & Sepulveda et al. (1997) \\
\hline Queen Maud Land & Ommatophoca rossi & 20 & $3.40 \pm 3.90$ & McClurg (1984) \\
\hline Gulf of St. Lawrence & P. groenlandica & 20 & $34.7 \pm 27.1$ & Wagemann et al. (1988) \\
\hline \multirow[t]{2}{*}{ Norway } & P. groenlandica & 8 & $0.33 \pm 0.08^{c, a}$ & Skaare et al. (1994) \\
\hline & & & $0.44 \pm 0.29^{\mathrm{c} b}$ & Skaare et al. (1994) \\
\hline \multirow[t]{2}{*}{ Norway } & P. vitulina & 3 & $1.96 \pm 2.54^{\mathrm{cod}}$ & Skaare et al. (1994) \\
\hline & & 2 & $10.48^{c, b}$ & Skaare et al. (1994) \\
\hline \multirow[t]{2}{*}{ Norway } & Halichoerus grypus & 18 & $22.36 \pm 11.94^{c a}$ & Skaare et al. (1994) \\
\hline & & 7 & $9.18 \pm 5.77^{c b}$ & Skaare et al. (1994) \\
\hline \multicolumn{5}{|l|}{ Spleen } \\
\hline Terra Nova Bay & L. weddellii & 1 & 24.0 & This study \\
\hline Syowa station & L. weddellii & 2 & $0.09^{c}$ & Yamamoto et al. (1987a) \\
\hline Eastern Australia & A. pusillus & 16 & $1.29 \pm 0.92^{c}$ & Bacher (1985) \\
\hline \multicolumn{5}{|l|}{ Pancreas } \\
\hline Terra Nova Bay & L. weddellii & 1. & 1.47 & This study \\
\hline \multirow[t]{2}{*}{ Syowa station } & L. weddellii & 2 & $0.05^{\mathrm{cid}}$ & Yamamoto et al. (1987a) \\
\hline & & & $0.02^{c b b}$ & Yamamoto et al. (1987a) \\
\hline aFemales, bMales. & sed as $\mu g g^{-1}$ wet wt & & & \\
\hline
\end{tabular}

As the environmental availability of methylmercury ( $\mathrm{MeHg}$ ), rather than total $\mathrm{Hg}$ concentrations, plays an important role in the uptake and transfer of $\mathrm{Hg}$ along food webs (Fowler et al. 1978, Bernhard \& Andreae 1984), the upwelling of waters around the coast of Terra Nova Bay may be an important factor for $\mathrm{Hg}$ bioaccumulation. The rate of $\mathrm{Hg}^{2+}$ methylation is much higher in deep than in shallow sediments, and high sub-thermocline concentrations of $\mathrm{MeHg}$ have been measured in the Pacific Ocean (Mason \& Fitzgerald
1990). In the surface waters of lakes, $\mathrm{MeHg}$ is photodegraded at very high annual rates (Sellers et al. 1996) and the volatilization of elemental Hg from the sea surface is an important component of the global cycle of this metal (Amyot et al. 1997). The fact that Terra Nova Bay is covered in ice for about 9 mo each year together with the low intensity of solar radiation, limited by the ice and the high density of algae in summer, may therefore enhance the persistence and bioavailability of $\mathrm{Hg}$ and $\mathrm{MeHg}$ in this coastal environment. 
The low temperature of Antarctic water affects the metabolic rate of organisms and could reduce the methylation of $\mathrm{Hg}^{2+}$ by heterotrophic microorganisms. However, demethylation processes are probably also reduced. In the same way the cold of the Ross Sea may decrease the uptake of $\mathrm{Hg}$ by marine organisms, but it also makes their excretion mechanisms less efficient. According to recent ecotoxicological research (Trudel \& Rasmussen 1997), assimilation of MeHg from food by fish is 5 to 10 times more efficient than that of inorganic $\mathrm{Hg}$, whereas the elimination of $\mathrm{MeHg}$ is 3 times slower and positively correlated with water temperature.

\section{Biomagnification of mercury in the Terra Nova Bay coastal food web}

The results of the present survey show that despite the very low concentrations of $\mathrm{Hg}$ in marine sediments, $\mathrm{Hg}$ levels in Terra Nova Bay organisms were only slightly lower than or in the same range as those reported for similar species from other parts of the world (Fowler 1990, Lock et al. 1992, Muir et al. 1992, Sadiq 1992, Szefer et al. 1993, Joiris et al. 1997, Stewart et al. 1997). Although on a fresh weight basis, it is difficult to cxplain the much lower concentrations measured in Adélie penguins and Weddell seals from near the Syowa station (Enderby Land; Honda et al. 1986a, Yamamoto et al. 1987a) and in marine invertebrates from the Antarctic Peninsula (Yamamoto et al. 1987b, Palmer Locarnini \& Presley 1995, de Moreno et al. 1997). The 3 coastal areas are very distant and differences in local factors such as volcanic emissions, water upwelling and animal ecology (e.g. feeding habits and growth rates) could modify the availability and bioaccumulation of Hg. However, some of the low values for Antarctic Peninsula marine organisms are rather astonishing because this region has the highest human impact and is also characterized by mineral deposits and volcanic activity. Moreover, in a wide survey of $\mathrm{Hg}$ in seals, penguins and fish from the Antarctic Peninsula Szefer et al. (1993) reported values higher than or in the same range as those measured at Terra Nova Bay.

Although Antarctic ocean waters are characterized by short food webs (the krill system), in coastal areas the biomass of euphausiids may be negligible and the webs may have a much more complex structure (JarreTeichmann et al. 1997). At Terra Nova Bay the zooplankton biomass is rather low (usually a few hundred individuals per $\mathrm{m}^{3}$ of water) and grazers are not food limited; thus the vertical flux of phytoplankton and organic detritus from the euphotic zone supports benthic communities which are very rich in species and numbers (Gambi et al. 1994). Like in most aquatic ecosystems (Mason et al. 1996) phytoplankton is prob- ably the main path of entry of $\mathrm{Hg}$ into coastal food webs. Mason et al. (1996) showed that passive uptake of uncharged, lipophilic chloride complexes is the main route of inorganic $\mathrm{Hg}$ and $\mathrm{MeHg}$ assimilation by diatoms and other phytoplankton. MeHg was accumulated in the cytoplasm of algal cells, whereas inorganic Hg was mainly bound to the cell membranes. Consequently the assimilation of $\mathrm{MeHg}$ by zooplankton was 4 times more efficient than that of inorganic $\mathrm{Hg}$ These differences in transfer efficiency along the web and in excretion efficiency between organic and inorganic forms of $\mathrm{Hg}$ are the main basis for biomagnification of $\mathrm{Hg}$ in organisms belonging to long and complex food chains.

To evaluate $\mathrm{Hg}$ biomagnification processes in marine food webs, comprehensive knowledge of the ecology of benthic organisms and their whole-body burden of chemical forms of $\mathrm{Hg}$ is necessary. Unfortunately, the ecology of many Antarctic marine organisms is not well known and our data concern total Hg concentrations. A comprehensive representation of the results (Fig 3) nevertheless shows a clear increase in $\mathrm{Hg}$ concentrations in the order phytoplankton < herbivorous organisms < benthic invertebrates feeding on detritus (either in suspension or deposited) < opportunistic scavengers and predators. For molluscs and vertebrate species, only concentrations in the digestive gland for liver) and muscle were considered. The vertebrate liver is not homologous and only partly analogous to the invertebrate digestive gland, however concentrations of $\mathrm{Hg}$ in these organs should mainly reflect inorganic forms of the metal. In contrast $\mathrm{MeHg}$, which has a biological half-life of years, is accumulated in mollusc and fish muscle mainly as a function of food contamination, species-specific metabolic pathways and age (i.e. exposure time; Bernhard \& Andreae 1984). In muscle of Trematomus bernacchij from Terra Nova Bay, for instance, up to $96 \%$ (median $80 \%$ ) of total $\mathrm{Hg}$ is $\mathrm{MeHg}$, whereas in liver, kidney and gonads this percentage is usually < 50\% (Capelli et al. 1990, Minganti et al. 1994). Fig. 3 also shows that although average Hg concentrations in the digestive gland of molluscs are in the same range as or slightly higher than those in liver of midwater-feeding fish (Chionodraco hamatus and Trematomus hansoni), the $\mathrm{Hg}$ content of muscle progressively increases from the filter-feeding molluscs (Adamussium colbecki and Laternula elliptica) to the gastropod Neobuccinum eatoni, to fish feeding on amphipods, copepods and euphausiids ( $T$. newnesi, $C$. hamatus; Iwami \& Kock 1990) and reaches the highest values in demersal fish ( $T$. hansoni and $T$. bernacchii) feeding through the year on fish, bivalves and epibenthic crustaceans (Vacchi et al. 1994, La Mesa et al. 1997).

Fish and zooplankton play a prominent role in controlling fluxes of MeHg to Antarctic seabirds and 


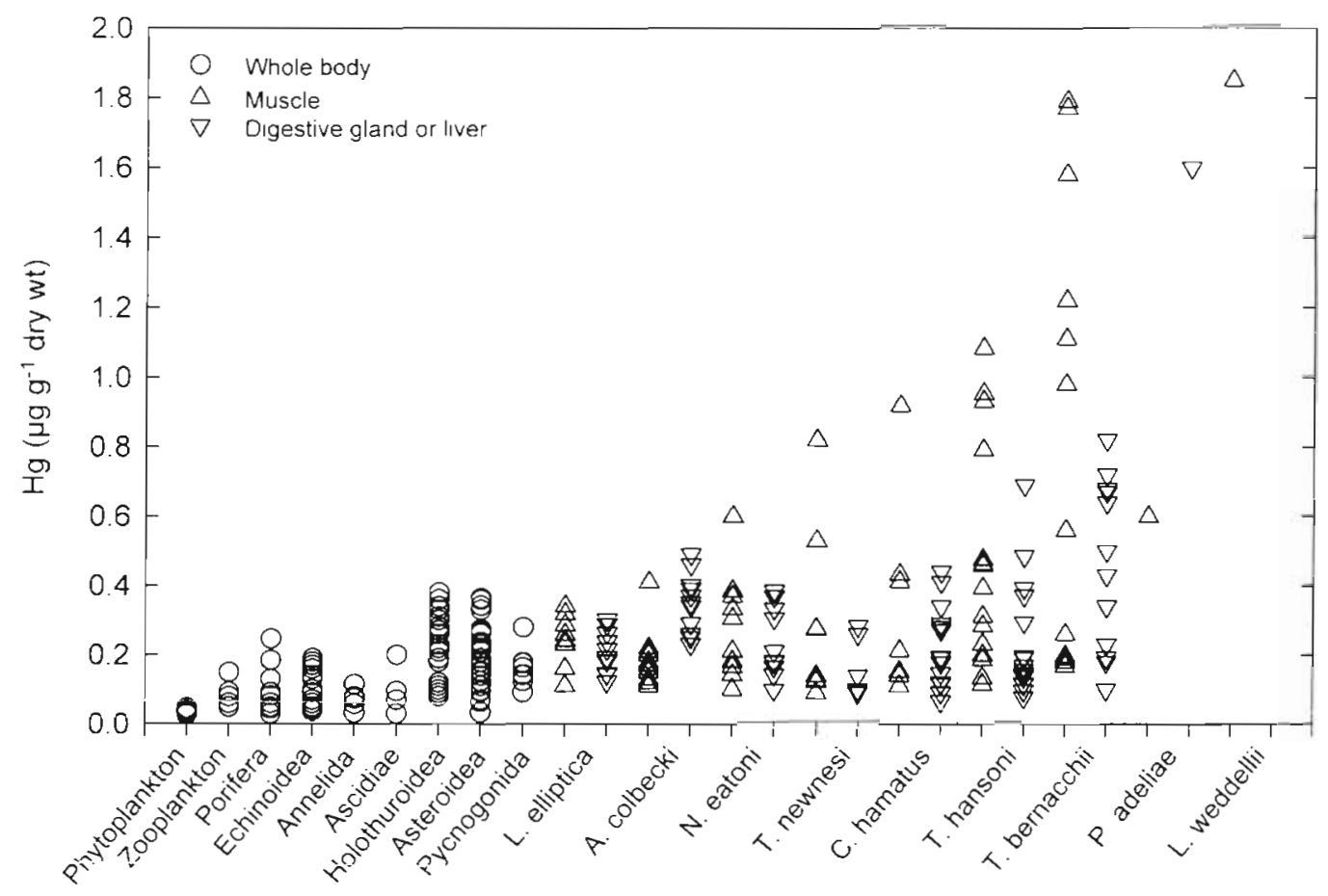

Fig. 3. Mercury concentrations in whole organisms and in muscle and liver (or digestive gland) of vertebrates and molluscs from Terra Nova Bay

marine mammals and the results of analytical determinations on seabird eggs, feathers and guano agree with available information on the ecology of the species studied (Young 1994, Kerry et al. 1995). For example, concentrations of $\mathrm{Hg}$ in eggs, which reflect dietary mercury uptake in the period prior to egg-laying (Monteiro \& Furness 1995), were twice as high in eggs of the snow petrel (a species migrating north in winter) than in eggs of the Adélie penguin (a circumpolar species mostly feeding in the Southern Ocean). The south polar skua has been seen farther south during summer than any other bird in the world, but is also known to winter (from late June to early October) in the northern Pacific and northern Atlantic (Court et al. 1997). This species can therefore accumulate higher $\mathrm{Hg}$ concentrations in contaminated environments before laying eggs on the Victoria Land coasts in November.

$\mathrm{Hg}$ levels in feathers reflect those in food eaten before the moulting period (Fimreite 1979), although interspecific differences in moulting and $\mathrm{MeHg}$ demethylation capacity may exist (Lock et al. 1992, Kim et al. 1996). Total $\mathrm{Hg}$ concentrations in adult feathers and chick plumage collected at Terra Nova Bay increased in the order snow petrel (mainly feeding on amphipods and copepods) < Adélie penguin (feeding on zooplankton and fish) < emperor penguin (mostly a fish-feeder) < south polar skua. The high $\mathrm{Hg}$ levels found in the latter are supported by its omnivo- rous diet consisting of marine organisms, eggs and chicks of penguins and skuas, adult snow petrels and human refuse from the scientific station (Court et al. 1997).

The quantitative ratio between total $\mathrm{Hg}$ concentration in liver and muscle of the Weddell seal was much higher than in penguins and fish. Pinnipeds have developed various detoxification mechanisms for $\mathrm{Hg}$, including metallothionein metabolism (Tohyama et al. 1986), the formation of selenide granules in the liver (Nigro \& Leonzio 1996) and excretion of MeHg through the fur (Wenzel et al. 1993).

\section{CONCLUSION}

Antarctic marine food webs are usually relatively simple and short, with krill playing a central role. However in coastal environments such as Terra Nova Bay, food webs are much more complex and the fact that $\mathrm{Hg}$ was found in a large number of marine organisms shows that benthic invertebrates are an important link between phytoplankton and fish. Although primary producers and consumers had total Hg concentrations lower than or close to the lower limit of ranges usually reported for related species from other marine areas, the involvement of benthic organisms in the food chain lengthens the chain and causes further biomagnifica- 
tion of $\mathrm{Hg}$. There was a sharp increase in $\mathrm{Hg}$ concentrations between benthic molluscs and muscle of demersal fish, fish-eating seabirds and Weddell seals Levels of the metal in tissues of this mammal and eggs and feathers of the Antarctic skua were similar to those reported in samples collected in the northern hemisphere.

Despite discrepancies with some previous data on marine organisms from other Antarctic coastal ecosystems, the results of this survey show that $\mathrm{Hg}$ concentrations in the biota of a remote environment, where input from local geochemical and man-made sources and from long-distance transport is negligible, are not necessarily low. As previously found for $\mathrm{Cd}$ in marine organisms from the same study area (Bargagli et al. 1996b), in pristine ecosystems the natural elemental composition of organisms may be altered by interactions between their ecophysiology and physico-chemical characteristics of the environment such as water temperature, light availability and upwelling of deep waters. These interactions should therefore be taken into account when establishing reference areas and/or baseline concentrations of $\mathrm{Hg}$ in marine organisms. Our results also show that caution is necessary when estimating the bioaccumulation and/or biological effects of metals only on the basis of data frum abiotic components of ecosystems.

Acknowledgements. This research was supported by funds of the PNRA (Programma Nazionale di Ricerca in Antartide). The authors thank Simonetta Corsolini for providing the samples of krill and penguin stomach contents.

\section{LITERATURE CITED}

Amyot M, Gill GA, Morel FMM (1997) Production and loss of dissolved gaseous mercury in coastal seawater. Environ Sci Technol 31:3606-3611

Bacher (1985) Mercury concentrations in the Australian fur seal Arctocephalus pusillus from SE Australian waters. Bull Environ Contam Toxicol 35:490-495

Bargagli R, Battisti E, Focardi S, Formichi P (1993) Preliminary data on environmental distribution of mercury in northern Victoria Land, Antarctica. Antarct Sci 5:3-8

Bargagli R, Broady PA, Walton DHW (1996a) Preliminary investigation of the thermal biosystem of Mt. Rittmann fumaroles (northern Victoria Land, Antarctica). Antarct Sci 8:121-126

Bargagli R, Nelli L, Ancora S, Focardi S (1996b) Elevated cadmium accumulation in marine organisms from Terra Nova Bay (Antarctica). Polar Biol 16:513-520

Berkman PA, Nigro M (1992) Trace metal concentrations in scallops around Antarctica: extending the Mussel Watch Programme to the Southern Ocean. Mar Pollut Bull 24: $322-323$

Bernhard M, Andreae MO (1984) Transport of trace metals in marine food chains. In: Nriagu JO (ed) Changing metal cycles and human health. Springer-Verlag Berlin, $p$ $143-167$

Boutron CF, Patterson CC (1986) Lead concentration changes in Antarctic ice during the Wisconsin/Holocene transition Nature 323:222-225

Capelli R, Minganti V, De Pellegrini R, Fiorentino F (1990) Mercury (total and organic) and selenium in Pagothenia bernacchii (Boulenger, 1902) from Terra Nova Bay (Antarctica). Results after two years of research. In: Cescon $P$ (ed) Environmental impact in Antarctica. National Research Council, Rome, p 47-54

Court GS, Davis LS, Focardi S, Bargagli R, Fossi C, Leonzio C, Marsili L (1997) Chlorinated hydrocarbons in the tissues of south polar skuas (Catharacta maccormicki) and Adélie penguins (Pygoscelis adeliae) from Ross Sea, Antarctica. Environ Pollut 97:295-301

D'Itri FM (1991) Mercury contamination - what we have learned since Minamata. Environ Monit Assess 19: $165-182$

de Mora SJ, Patterson JE, Bibby DM (1993) Baseline atmospheric mercury studies at Ross Island, Antarctica. Antarct Sci 5:323-326

de Moreno JEA, Gerpe MS, Moreno VJ, Vodopivez C (1997) Heavy metals in Antarctic organisms. Polar Biol 17 : $131-140$

Denton GRW, Burdon-Jones C (1986) Trace metals in algae from the Great Barrier Reef. Mar Pollut Bull 17:98-106

Fimreite $N$ (1979) Accumulation and effects of mercury on birds. In: Nriagu JO (ed) The biogeochemistry of mercury in the environment. Elsevier/North-Holland Biomedical Press, Amsterdam, p 601-627

Fowler SW (1986) Trace metal monitoring of pelagic organisms from the open Mediterranean. Environ Monit Assess $7: 59-78$

Fowler SW (1990) Critical review of selected heavy metal and chlorinated hydrocarbon concentrations in the marine environment. Mar Environ Res 29:1-64

Fowler SW, Heyraud M, La Rosa J (1978) Factors affecting methyl and inorganic mercury dynamics in mussels and shrimp. Mar Biol 46:267-276

Gambi MC, Lorenti M, Russo GF, Scipione MB (1994) Benthic association of the shallow hard bottoms of Terra Nova Bay, Ross Sea: zonation, biomass and population structure. Antarct Sci 6:449-462

Gaudette HE, Flight WR, Toner L, Folger DW (1974) An inexpensive titration method for the determination of organic carbon in recent sediments. J Sedim Petrol 44:249-253

Honda K, Yamamoto Y, Hidaka H. Tatsukawa R (1986a) Heavy metal accumulation in Adélie penguin, Pygoscelis adeliae, and their variations with the reproductive process. Mem Natl Inst Polar Res 40:443-453

Honda K, Yamamoto Y, Tatsukawa R (1986b) Heavy metal accumulation in the liver of Antarctic minke whales, Balaenoptera acutorostrata. Mem Natl Inst Polar Res 41: $10-12$

Innamorati M, Lazzara L, Massi L, Mori G, Nuccio C, Saggiomo V (1992) Research on the phytoplankton biomass in the Ross Sea in relation to environmental factors. In: Gallardo VA, Ferretti O, Moyano HI (eds) Oceanografia in Antartide. Centro EULA-Chile, Universidad de Concepcion, Concepcion, p 235-252

Iwami T, Kock KH (1990) Channichthydae. Icefishes. In: Gon O, Heemstra PC (eds) Fishes of the Southern Ocean. JLB Smith Institute of Ichthyology, Grahamstown, p 381-399

Jarre-Teichmann A, Brey $\Upsilon$, Bathmann UV, Dahm C, Dieckmann GS, Gorny M, Klages M, Pagés F, Plötz J, SchnackSchiel SB, Stiller M (1997) Trophic flows in the benthic shelf community of the eastern Weddell Sea, Antarctica. In: Battaglia B, Valencia J, Walton DWH (eds) Antarctic communities. Species, structure and survival. Cambridge 
University Press, Cambridge, p 118-134

Jolris CR, Ali IB, Holsbeek L, Kanuya-Kinoti M, TekeleMichael Y (1997) Total and organic mercury in Greenland and Barents Seas demersal fish. Bull Environ Contam Toxicol 58:101-107

Kerry KR, Clarke JR, Else GD (1995) The foraging of Adelie penguins at Bechervaise Island, Mac Robertson Land, Antarctica as determined by satellite telemetry. In: Dann P. Norman I, Reilly P (eds) The penguins. Surrey Beatty \& Sons, Chipping Norton, Australia, p 216-243

Kim EY, Murakami T, Saeki K, Tatsukawa R (1996) Mercury levels and its chemical forms in tissues and organs of seabirds. Arch Environ Contam Toxicol 30:259-266

Kurtz DD, Bromwich DH (1985) A recurring, atmospherically forced polynya in Terra Nova Bay. In: Jacobs SS (ed) Oceanology of Antarctic continental shelf. AGU Antarctic Research Series Vol 43, Washington, DC, p 177-201.

Kyle PR (1990) McMurdo volcanic group. Western Ross Embayment. In: LeMasurier WE, Thomson JW (eds) Volcanoes of the Antarctic Plate and Southern Oceans. AGU, Antarctic Research Series Vol 48, Washington, DC. p 19-25

La Mesa M, Vacchi M, Castelli A, Diviacco G (1997) Feeding ecology of two nototheniid fishes, Trematomus hansoni and Trematomus loennbergii, from Terra Nova Bay, Ross Sea. Polar Biol 17:62-68

Lock JWY, Thompson DR, Furness RW, Rartin I (1992) Metal concentrations in seabirds of the vew Zealand region. Environ Pollut 75:289-300

Mason RP, Fitzgerald WF (1990) Alkylmercury species in the equatorial Pacific. Nature 347:457-459

Mason RP, Reinfelder JR, Morel FMM (1996) Uptake, toxicity, and trophic transfer of mercury in a coastal diatom. Environ Sci Technol 30:1835-1845

Mauri M, Orlando E, Nigro M, Regoli F (1990) Heavy metals in the Antarctic mollusc Adamussium colbecki. Mar Ecol Prog Ser 67:27-33

McClurg TP (1984) Trace metals and chlorinated hydrocarbons in Ross seals from Antarctica. Mar Pollut Bull 15: $384-389$

Minganti V Capelli R, Fiorentino F, De Pellegrini R, Vacchi M (1995) Variations of mercury and selenium concentrations in Adamussium colbecki and Pagothenia bernacchii from Terra Nova Bay (Antarctica) during a five years period. Int J Analyt Chem 61:239-248

Minganti V, Fiorentino F, De Pellegrini R, Capelli R 11994 Bioaccumulation of mercury in the Antarctic bony fish Pagothenia bernacchii. Int J Environ Analyt Chern 55 $197-202$

Monteiro LR, Furness RW (1995) Seabirds as monitors of mercury in the marine environment. Water Air Soil Pollut 80: $851-870$

Muir DCG, Wagemann $\mathrm{H}$, Hargrave BT, Thomas DJ, Peakall DB, Norstromm RJ (1992) Arctic marine ecosystem contamination. Sci Total Environ 122:75-134

Nigro M, Leonzio C (1996) Intracellular storage of mercury and selenium in different marine vertebrates. Mar Ecol Prog Ser 135:137-1.43

Nigro M, Regoli F, Rocchi R, Orlando E (1997) Heavy metals in Antarctic molluscs. In: Battaglia B, Valencia J, Walton DWH (eds) Antarctic communities. Species, structure and survival. Cambridge University Press, Cambridge, p 409-412

Editorial responsibility: Otto Kınne (Editor). Oldendorf/Luhe, Germany
Norheim G (1987) Levels and interactions of heavy metals in sea birds from Svalbard and the Antarctic. Environ Poliut $47: 83-94$

Palmer Locarnini SJ, Presley BJ (1995) Trace element concentrations in Antarctic krill, Euphausia superba. Polar Biol $15: 283-288$

Sadiq M (1992) Toxic metal chemistry in marine environments. Marcel Dekker, Inc, New York

Sellers P, Kelly CA, Rudd JWM, MacHutchon AR (1996) Photodegradation of methylmercury in lakes. Nature 380 $694-697$

Sepulveda MS, Ochoa-Acuna H, Sundlof SF (1997) Heavy metal concentrations in Juan Fernandéz fur seals (Arctocephalus philippii). Mar Pollut Bull 34:663-665

Sheppard DS, Patterson JE, McAdam. MK (1991) Mercury content in Antarctic ice and snow: further results. Atmos Environ 25A:1657-1660

Skaare JU, Degre E, Aspholm PE, Ugland KI (1994) Mercury and selenium in Arctic and coastal seals off the coast of Norway. Environ Pollut 85:153-160

Stewart FM, Phillips RA, Catry P, Furness RW (1997) Influence of species, age and diet on mercury concentrations in Shetland seabirds. Mar Ecol Prog Ser 151:237-244

Szefer P, Czarnowski W, Pempkowiak J, Holm E (1993) Mercury and major essential elements in seals, penguins, and other representative faund of the Antarctic. Arch Environ Contam Toxicol 25:422-427

Thompson DR, Furness RW, Lewis SA (1993) Temporal and spatial variation in mercury concentrations in some albatrosses and petrels from the sub-Antarctic. Polar Biol 13: $239-244$

Tohyama C, Himeno SJ, Watanabe C, Suzuki T, Morita M (1986) The relationship of the increased level of metallothionein with heavy metal levels in the tissue of harbor seal (Phoca vitulina). Ecotoxicol Environ Saf 12:85-94

Trudel M, Rasmussen JB (1997) Modeling the elimination of mercury by fish. Environ Sci Technol 31:1716-1722

Vacchi M, La Mesa M, Castelli A (1994) Diet of two coastal nototheniid fish from Terra Nova Bay, Ross Sea. Antarct Sci 6:61-65

Vandal GM, Fitzgerald WF, Boutron CF, Candelone JP (1993) Variations in mercury deposition in Antarctica over past 34,000 years. Nature 362:621-623

Varekamp JC, Buseck PR (1986) Global mercury flux from volcanic and geothermal sources. Appl Geochem 1: $6.5-73$

Wagemann R, Stewart REA, Lockhart WL, Stewart BE, Povoledo M (1988) Trace metals and methyl mercury: associations and transfer in harp seal (Phoca groen/andica) mothers and their pups. Mar Mamm Sci 4:339-355

Wenzul C, Adelung D, Kruse H, Wassermann O (1993) Trace metad accumulation in hair and skin of the harbour seal, Phoca vitulina. Mar Pollut BuIl 26:152-155

Wolff EW (1990) Signals of atmospheric pollution in polar snow and ice. Antarct Sci 2:189-205

Yamamoto Y, Honda K, Hidaka H, Tatsukawa R (1987a) Tissue distribution of heavy metals in Weddell seals (Leptonychotes weddellii). Mar Pollut Bull 18:164-169

Yamamoto Y, Honda K, Tatsukawa R (1987b) Heavy metal accumulation in Antarctic krill Euphausia superba. Proc NIPR Symp Polar Biol 1:198-204

Young E (1994) Skua and penguin. Predator and prey. Cambridge University Press, Cambridge

Submitted: February 27, 1998; Accepted: May 15, 1998

Proofs received from author(s): July 14, 1998 